\title{
THE GLOBAL AND THE LOCAL IN MAX CAVALERA'S MUSIC PROJECTS
}

The career of the originally Brazilian trash/death metal musician Massimiliano Antonio 'Max' Cavalera represents an excellent case study for understanding the dynamic and complex processes of 'glocalisation' of music, in which the elements of the global and the local operate simultaneously across economic and cultural domains (Shuker 1994: 72). On the one hand, both Cavalera's exploration of trash/death metal as a popular music genre of Western origins, and his success on the global music market, can illustrate music's mobility across space - facilitated by the global "flows of capital, new technologies and styles" (Connell and Gibson 2003: 18) and dictated by the efforts of transnational entertainment companies to continue expanding their marketplace. On the other hand, Cavalera's hybrid music projects, which are based on a specific fusion of metal and World Music (in particular, local musical traditions of Brazil's indigenous peoples), and which have come to inaugurate his 'poetics' from the early 1990s onwards, exemplify music's ability to construct a particular geographical location and cultural identity. The present research aims to capture and unpack this dual nature of music - both its 'fluidity' and 'fixity' - in the era of globalization using Cavalera's musical career and output as an inspiring and instructive case in point.

(c) SES \& Jelena Gligorijevic, Etnomusikologian vuosikirja 2011, vol. 23, ss. 140-164. 


\section{The Extreme Metal Scene and Cavalera's Scenic and Musical Profile Development}

The analysis of the multidirectional ways in which the local and the global intersect in Cavalera's development can be underpinned by a number of theoretical frameworks drawing on the growing corpus of metal scholarship. The framing of the analysis could be, for instance, carried out through the concepts of genre (Walser 1993; Azevedo 2009), sound (Dunn 2004), or subculture (Brown 2003; 2007; 2009). However, the concept of scene seems to correlate most closely with the aims of the present research.

Having been introduced into academic discourse by Will Straw (1991) in his study on the alternative-rock and dance music scenes on both the local and translocal levels, this concept began to expand in its theoretical grounding and analytical usage, proving itself useful and credible in much popular music scholarship (see, for instance, Cohen 1991; Kruse 1993; Shank 1994; Olson 1998; Leonard 1998; etc.). In that respect, Bennett and Peterson's collection of papers (2004) using a scenes perspective for analysis of a wide range of popular music topics can serve as an excellent case in point. My approach is, however, largely informed by Kahn-Harris's (2007) advanced concept of scene, whose convincing application to the phenomenon of extreme metal music and culture makes it exceptionally suitable for the subsequent analysis of Cavalera's musical career. This concept, as explicated by Kahn-Harris, allows for a holistic, contextualized and socially grounded analysis, which looks at all musical and music-related activities within and around the scene in their totality and interrelatedness. It also implies a nonfixed definition of the scene by acknowledging its "constantly shifting, splitting and combining" nature but also its tendency to overlap with other more or less related scenes (Kahn-Harris 2007: 22-23). Another but no less important feature of the concept is its openness to different theories and methodologies and to everyday language, as well as its concern for both the global and the local dimensions of the scene (including the dynamics between the 'cores' and 'peripheries' and the corresponding issues of status, hierarchy and power within the scene).

As to the very definition of the extreme metal scene, Kahn-Harris employs the term in two ways: 1 ) as "a more flexible, loose kind of space" dwelling at the margins of the mainstream music industry, and shared by those who are devoted to extreme metal; and 2) as "local, face-to-face contexts of music making and con- 
sumption" (2006: 128-129). In other words, the extreme metal scene can be understood as a global music scene that consists of local scenes - "semiautonomous social networks supporting the production, dissemination, and consumption of [metal] recordings, fanzines, and other artefacts that operate to a great extent outside the formal commercial music industry" (Wallach 2009: 358). By thriving in locations (such as Scandinavia and Florida) that are slightly removed from the centers of global capitalist power, and by a relatively high interconnectedness between local scenes around the globe, the extreme metal scene has been rather decentralized from the very beginning of its establishment. These are all sufficient reasons to adopt the concept of scene in this paper as an analytical tool for explaining Sepultura's (that is, Cavalera's first band's) success on the global level, as well as for interpreting the meaning and particularities of this transnational popular music genre in the local (Brazilian) context.

In the present paper the theoretical implications of Cavalera's shifting from the local to the global extreme metal scene are discussed with respect to two instances of his musical career development. The first one concerns the very beginnings of his involvement with the Brazilian extreme metal scene, which coincided with the processes of that scene formation and development during the 1980 . The second phase of his extreme metal music production to be studied here is marked by his so-called 'world metal' and other cross-genre projects.

Like many other Brazilian metal musicians, Cavalera was initially playing and (re)producing a 'placeless' form of extreme metal but has nevertheless succeeded in establishing himself as a leading international metal musician. The aim of the first part of the present paper focusing on this early stage of Cavalera's musical career, is twofold. On the one hand, it seeks to illustrate that the global metal scene allows for the participation and exposure of metal musicians from most locations across the world. On the other, it intends to problematize the cultural globalization theories which imply that transnational cultural products might bring about a cultural 'grey-out' and a loss of local identities. Even if slightly decentralized, the global extreme metal scene replicates a highly asymmetrical structure of power relations within the global music industry. This means that flows of global capital and power within the extreme metal scene are also concentrated in Western developed countries. However, by looking at the specific political, socio-economic and cultural context within which the Brazilian metal scene emerged, the first part of this paper highlights those local meanings of 
this transnational popular music genre that confront what Feld (2000) calls the 'anxious' narratives about the 'Westernization' of 'native' musical cultures.

The second part of the paper looks into the various aspects of Cavalera's 'world metal' projects. First I assess the extent to which his blends of extreme metal with mainly Brazil's indigenous musical traditions fit into the definitions of World Music. The focus of my analysis moves then to an investigation of his motivation for such an approach to metal music. In addition, this part of the paper is also organized around the issues concerning both the reception and representation of these music cross-overs in public discourses. The discussion on the above topics aims to establish how a sense of authenticity and local/ethnic difference is conveyed in Cavalera's scenic profile and artistic agenda, and what effects and meanings such identity representations might produce. Since this discussion is largely framed by the theoretical concepts of World Music and metal studies, both of which form a small portion of research in ethnomusicology, popular music studies and sociology, the second part of the paper also seeks to underline the points at which the World Music and metal discourses intersect.

It is equally important to mention that my data consist of various media texts (such as online reviews and interviews) and monographs on Cavalera's personal, scenic and musical profile, which are at times subjected to the methodology of discourse analysis. In this paper discourse analysis is understood and exercised in a Foucauldian way, pointing to the bounds of the episteme, or discursive formation, within which opinions are formed and identities articulated. Applied to Cavalera's case, discourse analysis aims to shed light upon the epistemological assumptions and hidden motivations lying behind the discursive formation surfacing across a range of texts on Cavalera and operating at different institutional sites within the extreme metal scene.

\section{The Global and the Local within the Brazilian Metal Scene}

Although Brazilian trash, death and black metal came to play a significant role in the development of the global extreme metal scene (see Kahn-Harris 2007: 116), it was in the beginning marginalized not only from the global flows of extreme metal music but also the Brazilian popular music as a whole. The following extract from an interview with Max Cavalera provides evidence for 
the marginalized status of Brazilian trash/death metal in both the local and global context:

\begin{abstract}
When Max Cavalera and his brother Igor first went into a recording studio in Belo Horizonte, Brazil, to record what would become Sepultura's debut album, the engineers, who were used to recording only samba and bossa nova rhythms, thought the brothers and their band were crazy. "They thought we were lunatics," Cavalera says, laughing. "Like we had no idea of the real world. But we knew people outside of Brazil would like it, because we had heard Led Zeppelin and Black Sabbath records from these neighborhood guys who were into American records." (Magahern 2003.)
\end{abstract}

As Sepultura's early albums largely aimed at imitating the extreme metal sound from elsewhere in the world, one could easily jump to the conclusion that the Brazilian trash/death scene was shaped by the one-way flow of popular music from the Anglophone 'core' of the recording industry. This would also serve as a case in point for the 'cultural imperialism hypothesis' and its slightly different versions such as the 'cultural synchronization', 'cultural domination' and 'transculturation' theories (see Robinson et al. 1991). Be that as it may, a more fruitful approach to the theorization of cultural interaction between the West and the Rest has been proposed by the cultural sociologists investigating rock music as an 'Other' in non-Western cultures. As Frith puts it, "Rock [and its sub-styles] ... can be seen as the authentic articulation of a local identity in its very recognition of the complexity of that identity, of the global in the local and the local in the global" (2000: 314). In order to explain the meaning of Sepultura's early music in relation to both its local and global elements, it is therefore necessary to take into account the distinctive characteristics of the Brazilian metal scene at the time of its emergence, as well as the political, socio-economic and cultural factors that contributed to its formation.

The metal boom in Brazil took place in the mid-1980s during the political shift from the military twenty-year dictatorship (1964-1985) to the New Republic foundation with its first officially civilian and democratic government. Looking up to the global sound of prominent Anglophone metal bands (such as, Motörhead, Iron Maiden, Slayer, Metallica, Megadeth), and relying on the national heritage of their own hard rock music (known in the 1970 as rock pauleira), Brazilian 
metal bands began to emerge rapidly in the metropolises across the country (such as, Belo Horizonte, Santos, São Paulo, Rio de Janeiro). As a result, the national metal scene was being gradually constituted as a network of festivals (Rock in Rio and Belo Horizonte Metal Festival), independent labels (Belo Horizonte's Cogumelo Records, São Paulo's Baratos Afins and Devil Discos, and Rio's Heavy and Point Rock), magazines (Heavy and Rock Brigade, for example), and radio shows (São Paulo's Comando Metal, Belo Horizonte's Metal Massacre, and Rio's Guitarras para $o$ Povo). Due to the difficult material conditions under which the Brazilian metal scene was developing, and due to its significant proximity to the national punk scene, metal bands came to adopt the DIY ethic producing rather raw, lo-fi sound effects on their records, which differed considerably from highly polished Anglophone metal production.

English as a paradigmatic language for the transnational metal genre caused another difficulty for Brazilian metal bands as they were building their own vocabulary through a tedious process of translation. It would be tempting again to understand the Brazilian metal bands' adoption of English in terms of homogenization and power of global culture. Nevertheless, there were many underlying factors motivating Brazilian metal musicians to make this particular language choice and to replicate 'placeless' forms of extreme metal music in the early days. First, the fact that the very peak of metal development in Brazil coincided with the country's political transformation into democracy must not be overlooked. Within such a context, the pronounced inclination of a significant portion of Brazilian youth towards transnational metal sound and performance in English (which was previously a censored activity) could be interpreted as a celebration of the country's opening up to Western cultural influences. Second, during the 1990s, the unfavorable political and economic situation in the country pushed the Brazilian metal scene back to the margins, rendering metal 'a romantic hobby' for a majority of Brazilian musicians, and urging them to continue writing in English in order to gain access to the international markets (Azevedo 2009: 336-337).

Apart from the reason of necessity, copying the 'placeless' metal sound and singing in English can also be seen as politically motivated. According to some writers (see Wallach 2003; Kahn-Harris 2009), in countries which have traditionally been marginalized from the global flows of capital and culture, and where metal musicians produce music under difficult material conditions and/or the 
strictures of state censors, the faithful reproduction of the global metal sound in English opens up a possibility for musicians to express more freely their controversial political views, or it may simply function as "an escape from the constraints of locality" (Kahn-Harris 2009: 101). This is also very true for the Brazilian metal scene, within which the 'placeless' metal sung in English was utilized as a powerful tool for criticizing the nation.

Yet, similarly to the processes of a gradual 'indigenization' of Western popular music genres (such as rock and hip hop) in non-Western countries, the development and diversification of the global extreme metal scene over the course of the 1990 meant a shift from the 'placeless' to the more locally distinctive forms of extreme metal, and to a more frequently occurring preference for the native tongue. Within the South and Central American extreme metal scenes, the Brazilian one has benefited the most in that respect thanks to the globally-known and prestigious status of Brazilian music and culture (Kahn-Harris 2007: 116). This gradual move from criticizing to 'rediscovering' the nation will be demonstrated through the case study of Cavalera's first band Sepultura.

Having been founded in 1984 in Belo Horizonte, Sepultura had to undergo the same ordeal as other Brazilian metal bands. However, by 1987 when the Brazilian record label Cogumelo Records released Sepultura's second album Schizophrenia, both the global and Brazilian extreme metal scenes had largely been institutionalized and associated with one another. This permitted Sepultura to acquire an international reputation, a result of which was the band's seven-record deal with the American independent record company Roadrunner Records in 1988. Even if Sepultura shortly afterward evolved into "a leading global Metal band whose connections to Brazil had become less and less salient" (Kahn-Harris 2006: 131), the music they had created by the mid-199os nevertheless carried a particular set of meanings for the working- and lower-middle-class urban youth in postdictatorial Brazil. This music did not merely reflect the Brazilian youth's feelings of helplessness amidst the country's economic crises but it primarily symbolized a radical negation of the totality of the nation's music. As Avelar explains, "For large sectors of the urban youth of postdictatorial Brazil, heavy metal became at the same time a metaphor for the absence of a nation with which they could identify and an antidote against that exclusion" (2003: 341). Furthermore, as the campaign for direct and free elections in the rise of the first postdictatorial civilian government was betrayed by the liberal-conservative alliance, Sepultura's 
strategy of radical negation through the transnational trash/death metal sound, lyrics and iconography, was also directed at criticizing "the civic mythology of Brazilian democracy" and "the Christianizing-redemptive mythology of Milton Nascimento's music" which epitomized at the time the transformation of МРв (Música Popular Brasileira) into the agent of the New Republic's government (see Avelar 2002).

\section{Towards Cavalera's 'World Metal' Projects}

Even though Sepultura had sporadically been incorporating lyrics in Portuguese, Brazilian/Afrodiasporic polyrhythms and South American instruments (percussion and flutes) into a few of their trash/death metal songs by the mid-1990s (such as, 'Troops of Doom', 'Altered State', or 'Kaiowas'), it was the album Roots (Roadrunner Records, 1996) that marked the beginning of the band's (and, in particular, Max Cavalera's) involvement in World Music - above all, in the musics of Brazil's indigenous peoples. The most notable example of such fusion was the song 'Itsári' which was recorded with the Xavante tribe at their ancestral home in Mato Grosso (Brazil), and which resulted in a seamless blend of acoustic guitars with tribal percussion and chants. Some songs, on the other hand, brought in live drumming of the popular Brazilian percussionist Carlinhos Brown, while the Bahian instrument berimbau added a strong Brazilian flavor to the song 'Attitude'. Furthermore, a number of the album's songs referred more or less explicitly to some political, social, cultural and environmental topics from the Brazilian past (such as, 'Ambush' and 'Dictatorshit'), whereas the video clip for the album's opening song 'Roots, Bloody Roots' was paradigmatic for the concept of the entire album. It included references to 'tribal' drumming of black Bahian people painted with white stripes across their faces and bodies, several African traditional dances, capoeira (an artistic sport from the days when African slaves wore shackles on their wrists), numerous Roman Catholic symbols, and so on. In all, it was a curious mixture and display of both the 'primitive' and urban facets of Brazilian culture/music.

Max Cavalera's experiments in fusing trash/groove metal with World Music have been intensified ever since he left Sepultura (in 1996) and formed Soulfly (in 1997). As he stated in 2003: 
What people end up loving about Soulfly is the 40 different instruments that show up on the album, the world music influence that comes across - the things that they don't hear on a Metallica record. [...] Most bands don't want to get their hands into it. World music is scary to most metal heads. They think if they get caught playing something beautiful or melodic, their career's over. [...] A lot of bands are afraid to leave the formula of metal - what sells, what everybody's comfortable with. My attitude is: I want to play with even more different cultures. Morocco, east Africa. The weirder the combinations, the better. (Magahern 2003.)

A further discussion of Cavalera's musical career development from the 'placeless' into the place-bound extreme metal music production clearly necessitates the induction of World Music discourses. The label World Music itself bears multiple meanings due to the relatively long history and great dynamics of its circulation in a variety of discourses (i.e. academy, recording industry, everyday practice). This has been convincingly illustrated by Feld's (2000) comprehensive 'genealogy' of the term from the mid-1950s onwards. For the present purpose, I will be employing those definitions of World Music that seem to resonate most with the particularities of Cavalera's experiments with this popular music genre.

\section{Positioning Cavalera's 'World Metal' within World Music Discourses}

Drawing on Suvakovic's classification of the term World Music as a genre, transgenre or polygenre of popular music, Cavalera's 'world metal' projects can fit into the definition of World Music as a genre, understood "as a branch of contemporary Western or pro-Western popular music ... [which implies] the hegemony of contemporary Western popular music as opposed to traditional or post-traditional non-Western musical practices" (2006: 361). Following, alternatively, the distinction between World Music and Worldbeat (Taylor 1997), that is, between World Music and World Music Fusion (Golemovic 2004) - where the former puts an emphasis on the traditional origin of musics across the globe while the latter suggests their incorporation into the Anglophone popular music styles - Cavalera's 'world metal' projects unmistakably belong to the latter category.

The label World Music is clearly all-encompassing and permeable enough that Cavalera's 'world metal' projects can be regarded as part of the overall World 
Music production. Yet, by its context of production, distribution, promotion and consumption, Cavalera's eclectic mixes could not possibly match the commercial label of World Music which was invented in 1987 by several British independent record companies so as to facilitate the emerging commercial discourse on further production, classification and representation of non-Western music styles to Western audiences (see Brusila 2001; Feld 2000; Golemovic 2004). As Nenic (2006) demonstrates in her analysis of the ideological strategies of World Music, the concept of tradition plays a prominent role in vernacular and academic discourses on World Music. Even when understood in the broadest sense - as "every music with even a loose reference to folklore or ethnic sound, which is not dominated by the principle of fusion with pop music" (para. 11) - the concept of tradition rarely ever attends to Cavalera's complex, polyrhythmic, electrified, distorted, (often) politicized, and multi-ethnic hybrid forms. This point of view has also been validated by Avelar (2003) and Kahn-Harris (2006), both of whom argue that Cavalera's particular approach to the musical traditions of Brazil's indigenous peoples removes him from the discourse on World Music and its

"terrain of preservation, authenticity, recovery" (Avelar 2003: 343). This might be true especially when bearing in mind that Cavalera's music has never been produced, promoted, disseminated or consumed within the context of the global World Music network but within the context of the global metal scene. Even so, further analysis of Cavalera's 'world metal' projects will reveal not only that many of the ideological premises of World Music lie beneath Cavalera's work, but also that there are several points of juncture between the World Music and (global) metal discourses.

\section{Cavalera's Motivation for His 'World Metal' Production}

There are several possible explanations for Cavalera's decision to experiment with World Music while playing in both Sepultura and Soulfly. First, it might be argued that he was influenced by a growing tendency towards "plac[ing] more emphasis on place, cultural origin and nationhood" in the extreme metal production from the 1990s onwards (Kahn-Harris 2006: 131). Second, his international success in the 1990s brought him great prestige, financial security and institutional support within the global metal scene, and, consequentially, opened up 
space for much more artistic freedom in his music-making. Indeed, Kahn-Harris's research on the global metal scene confirms that "the ability and desire to articulate difference in metal is in many cases a function of a privileged position with global networks of power and capital" (2009: 101). That Cavalera's curiosity about and appreciation of different musics have been forged together with his personal financial interests, serving as an efficient marketing strategy for gaining popularity worldwide, can be grasped in his following statement:

What I do with Soulfly is what I believe in. It has a purpose to combine ... [various] styles, it's not just for show. Going to different places is a part of Soulfly. If you take that out of our sound we would become a very boring band. I think that we're one of the few bands the [sic] can really say that we have fans in Brazil, Australia and Iraq. A lot of bands can't say that. We also play places that other bands forget about... (David 2006.)

Third, Cavalera's bold attempts at fusing metal with World Music might be inspired by his own experience of a Third World musician living in a First World country (the USA). As he stated once: "Being from another culture and living in America for ten years has taught me a lot. And now I want to bring world music into metal" (Magahern 2003). Cavalera's case obviously demystifies the very notion of World Music which is "built upon the rigid dichotomy of first and third world countries - themselves thought of as occupying different locations, distant from and in opposition to each other" (Guilbault 2001: 181). The paradoxical situation in which Cavalera (as the Third World musician in the First World country) appropriates musics from his own and other deprived and/or developing countries/societies, points to "the hegemonic cultural and economic practices of those nation-states whose domination has forced people to emigrate or become transnationals" (Guilbault 2001: 188). It follows once again that Cavalera's musical career and his artistic projects underscore an asymmetrical structure of power relations within the system of global music production, distribution and promotion, where only those artists who have reached a capital-rich position can afford not only to experiment with different musical 'localities' and other syncretisms, but also to claim the greatest deal of artistic merits and financial benefits from such experiments. In other words, flows of musics across the national boundaries are always dictated and mediated by flows of capital and power in such a way 
as to match the politics and interests of transnational recording industries. And this is equally true for both World Music and global metal practices.

\section{Public Reception and Representation of Cavalera's Musical and Scenic Profile}

Despite Max Cavalera's public statements about his audience's affirmative response to 'world metal', the 'tribal' and ethnic influences on his projects from the album Roots onwards have been received in public with ambivalence. Both Sepultura and Soulfly have been praised for the bravery to display such diversity in their music, and simultaneously discredited for abandoning and transgressing 'pure' trash/death metal's boundaries. Drawing on Kahn-Harris's (2007) conclusions on the global extreme metal scene, it is reasonable to assume that the contradictory views on Cavalera's music reflect well the scene's permanent state of flux between remaining stable and homogenous, on the one hand, and welcoming change and diversity, on the other. The dialectical nature of the scene translates further into the distinction between what Kahn-Harris calls 'mundane' and 'transgressive' subcultural capital. As he clarifies, the former is "accrued through a sustained investment in the myriad practices through which the scene is reproduced" (such as, the canonical knowledge of extreme metal bands or any scene-oriented activity) (Kahn-Harris 2007: 122). The latter, by contrast, mostly applies to the scene's artists who are fully committed to radical individualism and innovation, as well as to the role of challenging the previously established boundaries and norms.

A display of 'transgressive' subcultural capital can certainly be acknowledged in Cavalera's unique, innovative, yet critical and detached approach to the scene; however, such an approach at the same time might entail the risk of exclusion from the scene. Correspondingly, I would like to argue that fans' laments for 'Max Cavalera-era Sepultura' suggest a shift in the composition of Cavalera's audience. From Sepultura's album Roots (1996) to Soulfly's album Dark Ages (2005), Cavalera was greatly influenced by nu metal - a metal subgenre which incorporates the elements of "grunge, hardcore, death metal, rap and funk musics", and which is characterized by a mixture of "downtuned guitars and metal riffs with alternately rapped, screamed and sung lyrics focusing on the dysfunction of the 
singer" (Udo cited in Kahn-Harris 2007: 133, 135). Due to its huge popularity by the late of the 1990s, nu metal has come to be perceived as 'trendy', 'depthless', 'weak', and potentially 'threatening' because of its display of black culture influences and its inclusion of female followers - both 'blackness' and femininity being traditionally treated as the undesirable and 'abjectified' elements within the global extreme metal scene. Or, in Kahn-Harris's words, "Nu metal has become an 'other' against which subcultural capital can be claimed" (2007: 135). Likewise, Cavalera's excursions into nu metal and World Music perhaps came to signify the 'Otherness' within the global extreme metal scene, blurring therefore the line between Cavalera's entitlement to 'transgressive' subcultural capital and his desire to orient himself towards wider music markets.

In addition, the ideas of Otherness and difference have been most often associated with the articulation of a sense of 'Brazilianness' in Cavalera's creative output. It is important to stress, however, that this way of coding the difference has become widely accepted within the global extreme metal scene due to the 1990s' increasing tendency in most destinations across the world to 'localize' the transnational extreme metal sound. Sepultura's/Soulfly's appropriation of "Brazil's more 'exotic' and 'exportable' musical genres, associated with the Afro-Brazilian heritage" (Connell and Gibson 2003: 156) gave rise to the reduced and sometimes racist interpretations of their personal and artistic profile. This is particularly evident in the fact that they were regularly marketed and represented in public discourses as 'jungle boys' or, alternatively, as 'tribe'. For instance, one Sepultura fan with the alias gotterdamerung admired Sepultura's album Roots for its "voodoo-jungle-back-to-tribes style with (for us, Europeans) exotic percussions and sounds" (Lyrics forum 2008). Likewise, Cavalera's numerous family and fan community members were described once by his colleague and neighbor Matt Strangwayes in tribal and overtly racist terms:

Not surprisingly, young metalheads tend to flock around the Cavalera clan.

"There is a big family vibe around them, even bigger than their own family," says Matt Strangwayes of the Phoenix band Greenhaven. [...] "There's a whole bunch of kids. Plus, you gotta [sic] consider that he comes from Brazil, where they don't have the limitations of the typical American family unit. There's that whole tribe thing, you know." (Magahern 2003.) 
In contrast to Avelar's (2003) assertion that Sepultura's members, being the 'boys' from a metropolis, could not identify with such 'absurd' labels, I would like to argue that they were in fact complicit and comfortable with this sort of representation. The band's identification with, for instance, the Xavante Indians, with whom they recorded the track 'Itsári', can be illustrated by the documented encounter between the two groups:

Igor [Sepultura's drummer and Cavalera's brother] says that the band identified a lot with the natives: "In a certain way, I think that we, as a band, had a lot of things in common with the Xavante Indians. We also lived on the edge of society, and our music and lifestyle is a long way from being assimilated and respected by that society." A spokesman of the tribe declared: "We had seen pictures of Sepultura and we knew that they were different, with their long hair and many tattoos. We also knew that they had been discriminated, like we were. Because of that we were very curious about them." (Barcinski \& Gomes 1999: chap. 9.)

In general, a particular emphasis on the 'primitive' and the 'urban' in Max Cavalera's projects might also give us solid grounds for considering the expressions of his style as compatible with 'neo-tribal' urban subcultures, which evolved from the Modern Primitive movement. As Winge explains:

\footnotetext{
Modern Primitives claim that body modifications [combined with other forms of cultural expressions, including music] are explorations of spirituality and attempts to gain a higher consciousness. Yet the Modern Primitive lifestyle suggests they are content in their modern, urban, Western culture, while they romantically pay homage to ethnic non-Western groups they have deemed primitive tribes (2003: 129).
}

The assumptions of 'neo-tribal' subcultural ideology underpin much of Cavalera's artistic agenda on the whole, but they became particularly prominent from the foundation of Soulfly (in 1997) until the release of the band's fifth album Dark Ages (2005). On one occasion Cavalera himself explained that he formed the band "with the idea of combined sounds and spiritual beliefs" (Argail 2008). Indeed, the religious and tribal themes dominate both the titles and the lyrics of 
Soulfly's albums and songs, whereas the groove/nu metal music style continues to be enriched with the elements of Brazilian and other musical 'localities'.

Both the World Music and global metal discourses are organized around the concept of authenticity. In the case of Cavalera's 'world metal' projects, this concept, as shown earlier, draws on the ideas of difference and exotica, and is put into practice through the specific construction of 'Brazilianness' as well as through the appropriation of "music legacies of different peoples that are part of the World Music culture" (Nenic 2006: para. 7). Contemporary cultural theory has long been critical of industrial World Music practices, not only because of the neo-colonial and racist connotations of their ideological premises, but also because they readily adhere to the Western listeners' ideas of the Otherness in music. According to Brusila, "The search for 'primitivism', 'direct expression of fundamental emotions', 'sincerity', 'playing from the heart' is once again an example of the bourgeois culture's need to find and define an 'Other', in many ways ideologically not far from the folklorists' search for a 'true soul' in folk music during the 19th century" (2001: 153). Curiously enough, Cavalera's 'neo-tribal' scenic profile and artistic agenda do not only continue to feed the Westerners' ideas about Brazil's 'exoticism', but they are also indicative of Cavalera's own phantasm about the 'authenticity' and 'incorruptness' of indigenous peoples' cultures, which have, in turn, inspired his work and lifestyle to a great extent. Either way, there is no doubt that Cavalera has capitalized on the attractive effect that such an articulation of authenticity produces for his global audience.

In addition, the extreme metal scene provides an alternative context for coding authenticity in Cavalera's music. By being marginalized and relatively removed from the global flows of capital and power concentrated in the international mainstream music industry practices, the extreme metal scene gives a sense of uniqueness and elitism to all its members. This fact automatically ascribes 'authenticity' value to Cavalera's metal music production. Furthermore, extreme metal discourses share a similar set of ideological, social and cultural meanings with rock discourses, and, to a much lesser extent, with World Music discourses. These are, for example, the ideological constructs of creativity, honesty, credibility, community and independence, and they are all embedded into the romantic notion of authenticity. In that respect, Cavalera's 'authenticity' cannot be disputed within the scene given his huge worldwide following (his 'tribe') and his long-standing musical career, signposted by contracts with the independent labels, and by his 
innovative musical procedures to the point of the genre's boundaries being transgressed. On top of this, Cavalera's hard work before his global success is congruent with the idea of a rock career - which is "based on [...] the belief that legitimate rock success [requires] years of struggle and 'dues paying'" (Frith cited in Negus 1996: 149) - and, therefore, enhances his image of an 'authentic' musician. As he confesses when remembering his early days with Sepultura:

Traveling on trains. Getting beat up by cops. Sleeping behind the stage. It's part of growing up. It's part of the nature of this stuff. [...] If you don't have that kind of background, you can't be a band like us. (Baird 1993.)

The fact that Cavalera has reached such a powerful position within the global metal industry neither confronts nor belittles his status of a credible artist. In contrast to the world of rock music in which creativity and commerce stand in a relationship of permanent tension, the extreme metal scene generally tolerates and in some cases welcomes profit and commerce. As Kahn-Harris asserts, "As long as the scene 'comes first' and an element of altruism is sustained, commercial imperatives are not necessarily problematic" (2007: 126). Cavalera's commitment to the scene perhaps should be sought in his inclusive approach towards metal musicians from those locations which are invisible in global terms. For instance, he has been cooperating and touring with several bands from Serbia, Russia, Turkey and France. As he explained:

...in Europe I like to tour without a support act and just have local bands. That's not something I can control, it's up to the venue. But I like the idea to give the opening bands a chance to play for the Soulfly audience. That's how I discovered Eyesburn from Serbia for example. Later on I worked with them on Prophecy [and Dark Ages]. Sometimes you never know when you discover a great band. With a package you would never have that. (David 2006.)

\section{Conclusion}

The multifaceted trajectories of Cavalera's musical career development - setting out from 'placeless' trash/death metal (re)production and evolving into the vari- 
ous 'world metal' and other cross-genre projects - allow for contradictory interpretations of his overall creative output from a cultural globalization theory perspective. Within such a theoretical framework, a clear dividing line can be drawn between optimistic and pessimistic, or what Feld (2000) calls 'celebratory' and 'anxious' narratives on popular music practices in the context of globalization.

Correspondingly, Cavalera's musical career in the early stage of its development can be understood in terms of the processes of music homogenization that conceal the hegemony of Western economic and cultural power and influence. Even if the circulation of metal music and musicians from a wide range of locations is 'relatively egalitarian' within the global extreme metal scene (KahnHarris 2009: 100), Sepultura's global success is more an exception to the rule than a proof that established transnational links within the scene work in a two-way direction and equally for the benefit of all its participants. Conversely, the penetration of Anglophone extreme metal music into the orbit of Brazilian popular music practices can be thought of as the very beginning of a creative dialogue between the West and the Rest. As shown in the previous analysis, for Sepultura and other Brazilian metal bands the reproduction of transnational extreme metal sound came to signify a powerful means for transgressing the constraints of locality, but also for negating the totality of the nation's music.

Further on, Max Cavalera's musical collaboration either with indigenous peoples across the globe or with various musicians from the margins of the global metal scene, raises the questions of ownership and disproportional power relations amongst musicians with respect to their ability to appropriate and distribute music around the world. Although Cavalera approached either group with no prejudices and paid royalties on each person's co-writing and participation in their joint music projects, in the last instance he was the one to capitalize on their musical input. However, as Guilbault highlights, "media imperialism is not perpetuated by musicians on their own, but is part of the cultural hegemony of the West built into the structures of the global music industry" (2001: 179).

While the 'anxious' narratives on global music industry practices call attention upon the further consolidation of music ownership in the centers of global power and capital through the exploitation and humiliation of indigenous music creators, the 'celebratory' narratives place an emphasis on the creative, liberating and empowering capacities of these cross-cultural encounters for all participants involved (see, for instance, Feld 2000; Feld \& Kirkegaard 2010; Nenic 2006). In 
light of the latter view, Cavalera's 'world metal' projects should thus be admired and praised for their capacity to incite a wide interest in traditional music cultures from all around the world, as well as for their creative output inspired by the idea of cultural "difference, diversity and dialogue" (Born \& Hesmondhalgh 2000: 26). His specific artistic agenda based on the exploration of World Music, different forms of metal and rock, primitivism, spirituality and various political issues could also be viewed "as a site on which new sorts of hybrid identity are being performed" (Frith 2000: 310). Indeed, the previous analysis has pointed to the great importance of 'neo-tribal' subcultural ideology for the articulation of Cavalera's identity. Another vital source of Cavalera's identification is certainly Brazil, to which he has regularly resorted ever since he became a well-established artist on the international metal scene. By rediscovering and recreating his home country's political and musical resources through his music-making, Cavalera began to redefine the very genre's boundaries and to challenge the way in which the nation had been represented in music.

The construction of the 'Brazilianness' (and, in general, of all other musical 'localities') in Cavalera's 'world metal' projects brings up the issues of authenticity and representation politics in a variety of discourses. These issues can once again be viewed through the lenses of both 'celebratory' and 'anxious' narratives about global music industry practices. From the former point of view, 'authenticity' in Cavalera's cross-cultural and cross-genre experiments can be associated with and celebrated for their hybridity, which further translates into the highly appreciated 'transgressive' subcultural capital within the extreme metal scene. In the foregoing analysis it has also been established that, from the scene's perspective, Cavalera embodies a sense of artistic 'authenticity' by assuming a set of ideological values that are widely shared with rock discursive practices (such as, honesty, rock career, community, independence, commitment to the scene). His prestigious status might be called into question only in the case of his cross-genre projects with nu metal and other popular music genres which are perceived as an Other within the extreme metal scene.

In addition, while the 'celebratory' narratives are affirmative of the ways in which Cavalera has coded the nation in music, seeing them as "the key to cracking open an exclusionary definition of national identity in music" (Avelar 2003: 343), the 'anxious' narratives are critical of the commodification of ethnicity and of the new forms of identity essentialization through music which are involved 
in that process (see Feld 2000; and Nenic 2006). It is undisputable that Cavalera has capitalized on the commodification of the 'Brazilianness' through his music projects. Moreover, a tendency towards the essentialization of national identity is self-evident in his personal, scenic and musical identification with the 'tribal' and the 'primitive'. Such identity representation does not only continue to reinforce the reduced and neo-colonial image of Brazil and Brazilians but it also serves the function of fulfilling Westerners' and Cavalera's own cultural desires and needs for an exotic Other.

According to Feld, "Musical globalization is experienced and narrated as equally celebratory and contentious because everyone can hear equally omnipresent signs of augmented and diminished musical diversity" (2000: 146). Indeed, what the 'celebratory' narratives identify in Cavalera's experimental projects as hybridity and diversification is precisely what the 'anxious' narratives view and classify as homogenization. From Baudrillard's and Erlmann's points of view, for instance, Cavalera's music could be easily qualified as "a postmodern pastiche where distinctions between tradition, authenticity, and modernity dissolve, demonstrating the 'loss of referentiality' and the triumph of the culture of the simulacrum" (Born \& Hesmondhalgh 2000: 28). That this interpretation might be plausible can be illustrated by the following review of Soulfly's album Prophecy:

\footnotetext{
Don't ask me about the ending of the song which is a Mexican-sounding horntune that could be imagined playing in the background of breaking a Pinata. A reader here on MR [Metal Reviews] later informed me that it is not a Mexican tune, but in fact Serbian march song titled "Mars na Drinu" (= March on River Drina). (Alexie 2004.)
}

Clearly, both the global and local meanings in Cavalera's overall music production within the context of World Music and global metal industry practices can be interpreted with a great degree of ambiguity. His creative output might be therefore well-understood as a symptom of the postmodern condition with the residues of modernism - "a field of cultural interactions in which modernist models of national identity in culture and postmodernist procedures of working with cultural samples are both effective" (Nenic 2006: para. 12). Although Cavalera's eclectic blends of extreme metal with various elements from a range of indigenous musical cultures and popular music genres often seem to have no 
meaning or point of reference, this does not mean that they do not adhere to the modernist ideal of authenticity in the process of self-reflexive identity construction. Hopefully, the case study of Max Cavalera's musical career has well demonstrated not only that the concept of authenticity and difference plays a prominent role in the exploration and articulation of cultural identities within the global metal scene, but also that such identity articulations reflect in full the complex and contradictory effects of the increasing globalization processes in today's society. 


\section{References}

\section{Data}

Aleksie (2004) "Reviews: Soulfly Prophecy" Metal Reviews, <http:/ /www.metalreviews.com/ reviews/detail.php3?id=2108> (accessed 29.03.2008).

Argail (2008) "Emotional Soulfly" MusicBabylon: Music Blogs and Videos, <http:/ /www. musicbabylon.com/argail/blog/emotional-soulfly> (accessed 29.03.2008).

Arve (2006) "Reviews: Sepultura Roots" The Metal Observer, <http:/ /www.metal-observer.com/ articles.php?lid=1\&sid=1\&id=10532> (accessed 29.03.2008).

AsIce Hardcore E-zine (2006) “Band Profile: Soulfly" Asice.net, <http:/ / www.asice.net/ bands/1205/> (accessed 31.03.2008).

Baird, Robert (1993) “The boys from Brazil transplanted to Phoenix, Sepultura strives for death metal with a conscience" Phoenix New Times, <http://www.phoenixnewtimes.com/content/ printVersion/160396/> (accessed 14.09.2011)

Barcinski, André \& Gomes, Silvio (1999) "Sepultura: Toda a História" (translated by Johan Sepulman \& Vinnie Dusted). São Paulo: Ed. 34, Sepultura.be, <http:/ / www.sepultura.be/ index.php? name $=$ Sections\&req $=$ viewarticle\&artid $=13 \&$ page $=1>($ accessed 15.09.2011)

Begrand, Adrien (2004) "Reviews: Soulfly Prophecy" Popmatters.com, <http:/ /www.popmatters. $\mathrm{com} / \mathrm{music} /$ reviews/s/ soulfly-prophecy.shtml> (accessed 24.03.2008).

Brown, Kit (2006) "Reviews: Soulfly Prophecy" Sputnikmusic.com, <http:/ /www.sputnikmusic. $\mathrm{com} /$ review/5151/Soulfly-Prophecy/> (accessed 24.03.2008).

David (2006) "Max Cavalera on Punk and Hardcore" AsIce Hardcore E-zine, <http:/ / www.asice. net/specials/107/> (accessed 31.03.2008).

Day, Tom (2006) “Interview: Soulfly" musicOMH.com, <http:/ / www.musicomh.com/ interviews/soulfly-2_0306.htm> (accessed 25.03.2008).

Hsu, Jean (2000) “CD Reviews: Soulfly Primitive" NY Rock (New York Rock), <http:/ /www. nyrock.com/reviews/2000/rss.asp> (accessed 29.03.2008).

Kaye, Don (2004) "cD Reviews: Soulfly Prophecy" Blabbermouth.net, <http:/ /www. roadrunnerrecords.com/blabbermouth.net/showreview.aspx?reviewID=169> (accessed 01.04. 2008).

Kicked In The Face: Metal Reviews and Opinions (2008) "Reviews: Sepultura Roots", Kickedintheface.com, <http://www.kickedintheface.com/reviews/Sepultura-Roots.htm> (accessed 29.03.2008). 
Lee, Cosmo (2005) “Reviews: Sepultura: Roots” Stylus Magazine, <http:/ /www.stylusmagazine. com/review.php?ID=3130> (accessed 09.04.2008).

Lyrics Forum (2011) “Ratamahatta by Sepultura - can someone explain this song (portugues) [sic]?" allthelyrics.com, < http:/ /www.allthelyrics.com/forum/lyrics-translation/42406-ratamahattaby-sepultura-can-someone-explain-this-song-portugues.html> (accessed 16.08.2011)

Magahern, Jimmy (2003) "Mad Max: Metal dad Max Cavalera rocks the thrash scene - and his Phoenix neighborhood" Music Phoenix New Times, <http:/ / www.phoenixnewtimes. com/2003-05-22/news/mad-max/4> (accessed 01.04. 2008).

Musician Biographies (2008) "Sepultura Biography" Musicianguide.com, <http:/ / www. musicianguide.com/biographies/1608001405/Sepultura.html $>$ (accessed 15.03. 2008).

Religion Facts: Religion, World Religions, Comparative Religion (2008) “Om" Religionfacts.com, <http://www.religionfacts.com/hinduism/symbols/aum.htm> (accessed 01. 04. 2008).

Rolling Stone Magazine (2008) "Reviews: Sepultura Roots" Rollingstone.com, <http:/ /www. rollingstone.com/artists/sepultura/albums/album/11666o/review/5946707/roots> (accessed 03.04.2008).

Sound of Metal: Metal Reviews and Metal Interviews (2008) "Review: Sepultura Roots" Soundofmetal.se, <http:/ / soundofmetal.se/index.php?page=sepulturarootsreview $>$ (accessed 25.03. 2008).

\section{Literature}

Avelar, Idelber (2002) “Defeated Rallies, Mournful Anthems, and the Origins of Brazilian Heavy Metal". Brazilian Popular Music \& Globalization. Eds. Charles A. Perrone \& Christopher Dunn. New York: Routledge. Pp. 123-135.

Avelar, Idelber (2003) "Heavy Metal Music in Postdictatorial Brazil: Sepultura and the Coding of Nationality in Sound". Journal of Latin American Cultural Studies 12:3, pp. 329-346.

Azevedo, Cláudia (2009) “Metal in Rio de Janeiro 1980's-2008: An Overview”. The Metal Void: First Gatherings. Eds. Niall W. R. Scott \& Imke Von Helden. Oxford (UK): Inter-Disciplinary Press. Pp. 331-340.

Bennett, Andy \& Peterson, Richard A. (eds.) (2004) Music Scenes: Local, Translocal, and Virtual. Nashville: Vanderbilt University Press.

Berger, Harris M. \& Carroll, Michael T. (eds.) (2003) Global Pop, Local Language. Jackson:

University Press of Mississippi. 
Brown, Andy R. (2003) "Heavy Metal and Subcultural Theory: A Paradigmatic Case of Neglect?". The Post-subcultures Reader. Eds. David Muggleton \& Rupert Weinzierl. Oxford; New York: Berg. Pp. 209-222.

Brown, Andy (2007) "Rethinking the subcultural commodity: The case of heavy metal t-shirt culture(s)". Youth Cultures: Scenes, Subcultures and Tribes. Eds. Paul Hodkinson \& Wolfgang Deicke. New York, London: Routledge, Taylor \& Francis Group. Pp. 63-78.

Brown, Andy R. (2009) “The Importance of Being Metal: The Metal Music Tabloid and Youth Identity Construction". The Metal Void: First Gatherings. Eds. Niall W. R. Scott \& Imke Von Helden. Oxford (UK): Inter-Disciplinary Press. Pp. 105-134.

Brusila, Johannes (2001) “Jungle Drums Striking the World Beat: Africa as an Image Factor in Popular Music". Encounter Images in the Meetings between Africa and Europe. Ed. M. Palmberg. Uppsala: Nordiska Afrikainstitutet. Pp. 146-161.

Brusila, Johannes (2001a) "Musical Otherness and the Bhundu Boys - The Construction of the 'West' and the 'Rest' in the Discourse of 'World Music'". Same and Other: Negotiating African Identity in Cultural Production. Eds. M. E. Baaz \& M. Palmberg. Stockholm: Nordiska Afrikainsitutet. Pp. 39-56.

Cohen, Sara (1991) Rock Culture in Liverpool. Oxford: Clarendon Press.

Connell, John and Gibson, Chris (2003) Sound Tracks: Popular Music, Identity, and Place. London: Routledge.

Dunn, Sam (2004) "Lands of Fire and Ice: An Exploration of Death Metal Scenes". Public: New Localities 29/2004, pp. 107-125, <http:/ / pi.library.yorku.ca/ojs/index.php/public/article/ viewFile/30359/27887> (accessed 18.08.2011)

Fairley, Jan (2001) "The 'Local' and 'Global' in Popular Music". The Cambridge Companion to Pop and Rock. Eds. Simon Frith, Will Straw \& John Street. Cambridge: Cambridge University Press. Pp. 272-289.

Feld, Steven (2000) "A sweet lullaby for World Music". Public Culture 12:1, pp. 145-71.

Feld, Steven \& Kirkegaard, Annemette (2010) “Entangled Complicities in the Prehistory of 'World Music': Poul Rovsing Olsen and Jean Jenkins Encounter Brian Eno and David Byrne in the Bush of Ghosts". Popular Musicology Online, <http:/ / www.popular-musicology-online. $\mathrm{com} /$ issues/04/feld.html> (accessed 19.08.2011)

Frith, Simon (2000) "The Discourse of World Music". Western Music And Its Others. Eds. Georgina Born \& David Hesmondhalgh. Berkeley: University of California Press. Pp. $305-322$.

Golemovic, Dimitrije O. (2004) "World Music". New Sound 24/2004, <http:/ / www.newsound. org.rs/eng/content.php?clanak_casopis_broj=24> (accessed 15.07.2011) 
Guilbault, Jocelyne (2001) "World Music". The Cambridge Companion to Pop and Rock. Eds. Simon Frith, Will Straw \& John Street. Cambridge: Cambridge University Press. Pp. 176-192.

Kahn-Harris, Keith (2006) "'Roots'?: The Relationship between the Global and the Local within the Extreme Metal Scene". The Popular Music Studies Reader. Eds. Andy Bennett, Barry Shank \& Jason Toynbee. London: Routledge. Pp. 128-134.

Kahn-Harris, Keith (2007) Extreme metal: music and culture on the edge. Oxford: Berg.

Kahn-Harris, Keith (2009) "How Diverse Should Metal Be? The Case of Jewish Metal, Overt and Covert Jewishness". The Metal Void: First Gatherings. Eds. Niall W. R. Scott \& Imke Von Helden. Oxford (UK): Inter-Disciplinary Press. Pp. 95-104.

Kruse, Holly (1993) "Subcultural Identity in Alternative Music Culture”. Popular Music 12:1, pp. $31-43$.

Leonard, Marion (1998) "Paper Planes: Travelling the New Grrrl Geographies". Cool Places: Geographies of Youth Cultures. Eds. Tracey Skelton \& Gill Valentine. London: Routledge. Pp. $101-118$.

Negus, Keith (1996) Popular Music in Theory: An Introduction. Cambridge: Polity Press.

Nenic, Iva (2006) “World Music: From Tradition to Invention". New Sound 27/2006, <http:/ / www.newsound.org.rs/eng/content.php?clanak_casopis_broj=27> (accessed 15.07.2011)

Olsen, Dale A. (2000, 3rd ed.) Musics of Many Cultures: Study Guide E Workbook. Dubuque, Iowa: Kendall/Hunt publishing.

Olson, Mark J. V. (1998) “'Everybody Loves Our Town': Scenes, Spatiality, Migrancy”. Mapping the Beat: Popular Music and Contemporary Theory. Eds. Thomas Swiss, John Sloop \& Andrew Herman. Malden and Oxford: Blackwell. Pp. 269-289.

Robinson, Deanna C. et al. (1991) Music at the Margins: Popular Music and Global Cultural Diversity. Newbury Park; London; New Delhi: Sage.

Shank, Barry (1994) Dissonant Identities: The Rock ' $n$ ' Roll Scene in Austin, Texas. Hanover, NH: Wesleyan University Press.

Shuker, Roy (1994) “'We are the world': State music policy, cultural imperialism, and globalisation" (Chapter 4). Understanding Popular Music. London: Routledge. Pp. 67-82.

Straw, Will (1990 [1983]) "Characterizing Rock Music Culture: The Case of Heavy Metal”. On Record: Rock, Pop, and the Written Word. Eds. Simon Frith \& Andrew Goodwin. London: Routledge. Pp. 97-110.

Straw, Will (1991) "Systems of Articulation, Logics of Change: Communities and Scenes in Popular Music". Cultural Studies 5:3, pp. 368-388.

Suvakovic, Misko (2006) Diskurziona analiza [Discursive Analysis]. Belgrade: Univerzitet umetnosti u Beogradu. 
Taylor, Timothy D. (1997) Global Pop: World Music, World Markets. New York, London: Routledge. Wallach, Jeremy (2009) “Distortion Drenched Dystopias: Metal and Modernity in Southeast Asia". The Metal Void: First Gatherings. Eds. Niall W. R. Scott \& Imke Von Helden. Oxford (U K): Inter-Disciplinary Press. Pp. 358-366.

Walser, Robert (1993) Running with the Devil: Power, Gender, and Madness in Heavy Metal Music. Hanover; London: Wesleyan University Press/University Press of New England.

Winge, Theresa M. (2003) “Constructing 'Neo-Tribal' Identities through Dress: Modern Primitives and Body Modifications". The Post-subcultures Reader. Eds. David Muggleton \& Rupert Weinzierl. Oxford; New York: Berg. Pp. 119-132. 